\title{
The incidence of malnutrition between 1 and 5 years of age on the basis of the preventive primary care data
}

\author{
M KÁDÁR ${ }^{1,2}$, GJ SZÖLLÖSI ${ }^{3}, \mathrm{SZ} \mathrm{MOLNÁR}^{2,4}$ and L SZABÓ ${ }^{5,6,7 *}$ \\ ${ }^{1}$ National Healthcare Services Center, Budapest, Hungary \\ ${ }^{2}$ Pathological Sciences PhD School, Semmelweis University, Budapest, Hungary \\ ${ }^{3}$ Division of Biostatistics and Epidemiology, Department of Preventive Medicine, Faculty of Public Health, University of Debrecen, \\ Debrecen, Hungary \\ ${ }^{4}$ Department of Dietetics and Nutrition Sciences, Faculty of Health Science, Semmelweis University, Budapest, Hungary \\ ${ }^{5}$ Department of Family Care Methodology, Faculty of Health Science, Semmelweis University, Budapest, Hungary \\ ${ }^{6}$ Department of Paediatrics-Pulmonology, Heim Pál National Pediatric Institute, Budapest, Hungary \\ ${ }^{7}$ Velkey László Child Health Centre, Borsod Abaúj Zemplén County Central Hospital, University Teaching Hospital, Miskolc, Hungary
}

(Received: January 15, 2019; revised manuscript received: March 18, 2019; accepted: March 25, 2019)

\begin{abstract}
Introduction: Malnutrition inhibits children from normal development and leads to irreversible consequences with respect to mental and physical performance. Materials and methods: We analysed the aggregate data in the 2013-2015 reports of regional visiting nurses on the nutritional status of Hungarian children at the ages of 1, 3, and 5 years. In the regions of Hungary, stratum-specific proportions were calculated with $95 \%$ confidence intervals for the proportion of children with lower than a 10th percentile score. Results: The proportions of malnutrition among children whose score was below the 10 th percentile nationwide were $8.14 \%$ [8.03\%-8.25\%] at age 1 , $6.87 \%$ [8.03\%-8.25\%] at age 3, and 5.68\% [5.59\%-5.78\%] at age 5. In all three age groups, the proportion of children below the 10th percentile was significantly lower in the Central Hungarian region than in the national reference proportion and in Northern Hungary and the Southern Great Plain. Discussion and conclusions: These results indicate that Hungary's incidence of malnutrition is no better than the worldwide average. To improve this situation, Hungarian healthcare professionals must at least begin following a precise, standardized protocol for the compulsory assessment of nutritional status in the framework of their reporting on the primary care of children.
\end{abstract}

Keywords: nutritional status, percentiles, malnutrition, stratum-specific proportions, visiting nurses

\section{INTRODUCTION}

Several nutrition-related factors affect the development of children, from their conception to adulthood. Their wider and closer environments play a role, in addition to the genes with which they are born. Although it has been pointed out on multiple occasions, the inevitable role of the family cannot be overemphasized since the effects - healthy or pathological - coming from one's family exert lifelong impacts to the development and the health of a child [1]. As in the development of moving or speech, the family similarly plays an important role in the habits of nutrition [2]. Breastfeeding of newborns plays an important role in the physical as well as in the psychic development of children. Psychosocial risk factors that may exist in families (e.g., maternal depression, aggression within the family, or some kind of addiction) may lead to difficulties in feeding and may cause regression in development or malnutrition similar to any other regulatory malfunction [3]. Inappropriate food security, nutritional or familial metabolic disorders, and other acute or chronic diseases could be among the reasons behind weight-gain deficit $[4,5]$.
Consequences of malnutrition could even result in irreversible damage to the organism of a maturing child as well as the continuous monitoring of anthropological parameters in order to evaluate the healthy development and prevent irreversible complications. In the majority of children surviving malnutrition, reduced mental and physical activity is characteristic, and chronic diseases can be observed. Deficits in neurological and cognitive development can be definitely perceived in adulthood, which might negatively impact even the economic development of a given country. Malnutrition could be a risk factor in several contagious diseases, as well as mortality $[6,7]$. The deficit in physical development could be a major public health problem in developing countries. According to data published at the beginning of the 2000s, malnutrition globally could be held responsible for almost one third of the mortality of children less than 5 years of age; furthermore, 60 million children

* Corresponding author: Dr. László Szabó; Department of Family Care Methodology, Faculty of Health Science, Semmelweis University, Vas Street 17, Budapest 1082, Hungary; Phone: +3630941 5842; E-mail: szabo.laszlo.md@gmail.com

This is an open-access article distributed under the terms of the Creative Commons Attribution 4.0 International License, which permits unrestricted use, distribution, and reproduction in any medium, provided the original author and source are credited, a link to the CC License is provided, and changes - if any - are indicated. (SID_1) 
were modestly and 13 million children were severely undernourished worldwide $[6,8]$. According to the data published by WHO and UNICEF in 2011, the number of undernourished children less than 5 years of age decreased from 58 million in 1990 to 52 million (8\%) in 2011, which resulted in a decrease by $11 \%$ for the given period [9]. In 2016, however, there was no significant change in the data. Still 51.7 million children, i.e., 7.7\% of children aged between 0 and 5 years, were suffering from malnutrition [10]. In Central Europe, the rate of malnutrition was between $1.0 \%$ and $12.8 \%$ [11].

Today in Hungary, the health and nutritional status of children aged between 0 and 6 years are continuously monitored and evaluated by the experts in primary child healthcare in the framework of mutual cooperation, in accordance with the legal rules and professional guidelines [12]. Decree 51/1997 (XII. 18.) NM concerning health services and the certification of screening examinations aimed at the prevention and early diagnoses of diseases which are available within the statutory health insurance scheme accurately specifies screening examinations to be performed at given ages. It also prescribes in detail that visiting nurses should measure height and weight at the age of $1,3,6$, and 12 months, and yearly afterwards until the age of 6 years, as well as assess development and nutritional status on the basis of the domestic standards [13].

Reference data (average, normal distribution, and percentile) used in practice are retrieved from the data of National Longitudinal Child Heightening Examination (by its Hungarian acronym: "OLGYV"), which is the first child heightening examination in Hungary performed on a sample representing the child population. OLGYV produced reference averages and percentiles covering the entire spectrum of body measurements from birth to the age of 18 years, in which data are of assistance in the timely recognition of poor physical development and malnourishment in early childhood [14].

Regional visiting nurses assess nutritional status primarily on the basis of the reference averages and percentiles of the body weight, calculated body mass index (BMI), or - in the absence of BMI - body weight average and percentiles corresponding to body height (longitudinal growth). Data so received are evaluated in comparison with the percentile table or curve [15]. Percentiles show the distribution of the measurements of the child population, i.e., a given figure indicates the percentage figure by which the body measurement of a child is larger or smaller than the body measurement of other children of the same sex and age [4].

Intense care is needed for a child whose measured figure is under the 3rd percentile. Such a figure indicates malnutrition, where the underlying cause could be a congenital or chronic disease or the bad financial position of the family. In the cases of such children, close monitoring and further specialist medical examinations are required. Figures between the 3rd and 10th percentiles indicate thinness that requires close monitoring in the course of care $[4,16]$.

This study aimed at mapping the rate of malnutrition in Hungary, assessing the degree of pathological disorder recognized by visiting nurses, and investigating regional differences in order to draw attention to the existing situation and to encourage domestic professionals to solve problems.

\section{METHODS}

We used data from the publicly available annual reports titled "Summary of reports of visiting nurses" from the years 2013 to 2015. Data related to primary healthcare were retrieved from the tables of the Healthcare Statistical Yearbook, accessed through the e-shelf services of the Central Statistical Office (KSH) [16]. Data sources used in this study present the results of body weight and body height measurements based on the assessment of nutritional status performed in the framework of compulsory age-bound malnutrition screening of children aged 1, 3, and 5 years. With regard to the nutritional status of children, visiting nurses regularly produce three indicators, one of which indicates overnutrition, and the remaining two indicate weight deficit. This study is based on children under the 3 rd percentile (indicating a significant weight deficit) and between the 3rd and the 10th percentiles (indicating thinness).

Descriptive statistics were performed on the merged data of the period between 2013 and 2015, focusing on children aged 1,3 , and 5 years $(n=378,424)$. Stratum-specific proportions for each age group were calculated for each region regarding the rates of children under the 10 th percentile (under 3 percentiles and between 3 and 10 percentiles). Significant differences related to each proportion of the regions were evaluated by $95 \%$ confidence intervals, which were represented by Y-error bars on the bar charts. Those cases were considered as significant where the $95 \%$ confidence intervals did not overlap.

\section{RESULTS}

According to data, we retrieved from reports written by Hungarian visiting nurses during compulsory malnutrition screenings and nutritional assessments of the children they visited at the age of $1,2.78 \%(n=2,381)$ in $2013,2.83 \%$ $(n=2,275)$ in 2014 , and $3.16 \%(n=2,787)$ in 2015 were scored as having a significant weight deficit, i.e., measurements placed them under the 3rd percentile. In Hungary, during the period from 2013 to 2015, the incidence of children characterised by percentiles between $3 \mathrm{rd}$ and 10 th was $5.19 \%(n=4,448), 5.20 \%(n=3,191)$, and $5.23 \%(n=4,617)$ in 2013,2014 , and 2015, respectively. The number of cases between 2013 and 2015, measured in the course of age-bound compulsory malnutrition screenings and nutritional assessments, is shown in Table 1.

Compared to the above, the incidence of children scored as having a weight deficit at the age of 3 years can be deemed modest. The percentages of children who were scored below the 3 rd percentile were $2.15 \%(n=1,735)$ in $2013,2.14 \%(n=1,621)$ in 2014 , and $2.30 \%(n=1,887)$ in 2015. The percentages between the 3 rd and 10th percentiles were $4.53 \%(n=3,645)$ in $2013,4.68 \%(3,541)$ in 2014 , and $4.78 \%(3,920)$ in 2015 , respectively.

The percentages of children scored as having a weight deficit at the age of 5 years were even lower. Percentages 
Table 1. Number of cases between 2013 and 2015, perceived in the course of age-bound compulsory screening examinations

\begin{tabular}{|c|c|c|c|c|c|c|c|c|c|}
\hline \multirow[b]{2}{*}{ Year } & \multicolumn{3}{|c|}{1 year of age } & \multicolumn{3}{|c|}{3 years of age } & \multicolumn{3}{|c|}{5 years of age } \\
\hline & $\begin{array}{c}\text { All } \\
\text { examined } \\
\text { children }\end{array}$ & $\begin{array}{c}\text { Under } 3 \\
\text { percentiles }\end{array}$ & $\begin{array}{c}\text { Between } 3 \\
\text { and } 10 \\
\text { percentiles }\end{array}$ & $\begin{array}{c}\text { All } \\
\text { examined } \\
\text { children }\end{array}$ & $\begin{array}{c}\text { Under } 3 \\
\text { percentiles }\end{array}$ & $\begin{array}{c}\text { Between } 3 \\
\text { and } 10 \\
\text { percentiles }\end{array}$ & $\begin{array}{c}\text { All } \\
\text { examined } \\
\text { children }\end{array}$ & $\begin{array}{c}\text { Under } 3 \\
\text { percentiles }\end{array}$ & $\begin{array}{c}\text { Between } 3 \\
\text { and } 10 \\
\text { percentiles }\end{array}$ \\
\hline 2013 & 85,625 & 2,381 & 4,448 & 80,429 & 1,735 & 3,645 & 85,369 & 1,458 & 3,365 \\
\hline 2014 & 80,501 & 2,275 & 4,191 & 75,615 & 1,621 & 3,541 & 80,894 & 1,509 & 3,097 \\
\hline 2015 & 88,123 & 2,787 & 4,614 & 81,970 & 1,887 & 3,920 & 79,897 & 1,541 & 3,024 \\
\hline
\end{tabular}

below the 3 rd percentile were $1.70 \%(n=1,458)$ in 2013 , $1.86 \%(n=1,509)$ in 2014 , and $1.92 \%(n=1,541)$ in 2015 . Percentages for children between the 3rd and 10th percentiles were $3.94 \%(n=3,365)$ in $2013,3.82 \%(n=3,097)$ in 2014 , and $3.78 \%(n=3,024)$ in 2015 .

The overall national percentage of malnourished children at age 1 was $8.14 \%$ (95\% CI: [8.03\%-8.25\%]). The overall percentage of malnourished children was significantly lower in the Central Hungary region, where it was $6.48 \%(95 \%$ CI: $[6.31 \%-6.65 \%])$. Significantly higher percentages were found in Northern Hungary, where it was $10.99 \%(95 \%$ CI: $[10.64 \%-11.34 \%)$, in the Southern Great Plain, where it was $8.98 \%$ (95\% CI: [8.65\%-9.30\%]), and in Western TransDanubia, where it was $8.68 \%$ (95\% CI: [8.32\%-9.04\%]).

The overall national percentage of malnourished children at age 3 was $6.87 \%$ (95\% CI: [6.77\%-6.97\%]). Similar to the results of the malnutrition screenings and nutritional assessments conducted on children at age 1 , the percentage was significantly lower in the Central Hungary region, where it was $4.77 \%$ (95\% CI: [4.62\%-4.92\%]). The percentages were significantly higher than the national percentage in Northern Hungary, where it was $8.99 \%$ (95\% CI: [8.68\%-9.31\%]), in the Southern Great Plain region, where it was $8.83 \%$ (95\% CI: [8.50\%-9.16\%]), and in the Northern Great Plain region, where it was $7.62 \%$ (95\% CI: [7.33\%-7.90\%]).

The overall national percentage of malnourished children at age 5 was $5.68 \%$ (95\% CI: [5.59\%-5.78\%]). Again, the percentage was significantly lower in the Central Hungary region, where it was $4.24 \%$ (95\% CI: [4.09\%-4.38\%]). Again, the percentages were significantly higher than the national percentage in Northern Hungary, where it was 7.88\% (95\% CI: [7.58\%-8.19\%]), in the Southern Great Plain, where it was $6.83 \%$ (95\% CI: [6.55\%-7.12\%]), and in the Northern Great Plain, where it was $6.02 \%(95 \%$ CI: $[5.78 \%-6.26 \%]$ ) (Figure 1).

\section{DISCUSSION AND CONCLUSIONS}

In Hungary today, the health and nutritional status of young children are continuously monitored and evaluated by the experts on primary child healthcare, in a framework of mutual cooperation, according to the legal rules and professional guidelines [12]. An overall picture of the physical development and nutritional status of young children can be retrieved primarily from the data collected by regional visiting nurses. In addition to organising statutory malnutrition screenings and nutritional assessments in accordance

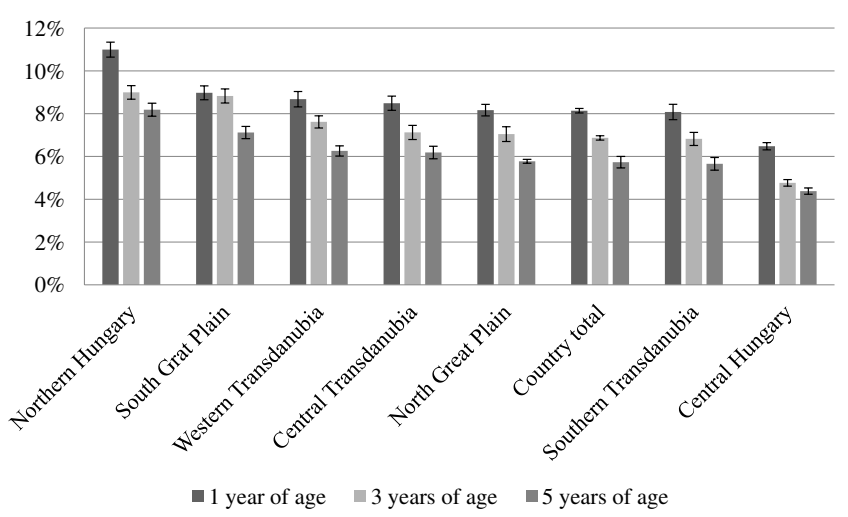

Figure 1. Percentage of children aged 1,3 , and 5 years with a value below 10th percentile by region between 2013 and 2015 (error bar: standard error)

with the relevant legal rules and professional guidelines, conducting examinations within their scope of competence, and determining further treatments based on the results of such examinations, regional visiting nurses are responsible for the management of comprehensive child healthcare documentation. Visiting nurses are also required by law to provide data on the health status of children in the form of annual (monthly) reports [16-18].

As in other countries, there were regional differences [8], but, according to this study, of the data collected from 2013 to 2015 , averaged for Hungary as a whole, $8.14 \%$ of children at age $1 ; 6,87 \%$ at age 3 ; and $5.68 \%$ at the age 5 , were malnourished. In the Central Hungary region, in all three age groups, the percentage of children under the 10th percentile, i.e., who were scored as having either a significant weight deficit or as being thin, was significantly lower than the national average. In Northern Hungary and in the Southern Great Plain region, however, the percentage of malnourished children was higher than the national average. The figures for Northern Hungary, where 10.99\%, 8.99\%, and $7.88 \%$ of children at ages 1,3 , and 5 , respectively, were malnourished.

The malnutrition percentages in Hungary decreased with increasing age. On the contrary, an Ethiopian study found that the percentage of children with malnutrition increased with age [8]. Similar statements can be made about the Congo and South Africa [19, 20]. Falling rates of breastfeeding with the increase of age play a significant role in this phenomenon.

On the basis of the available data on the global prevalence of malnutrition, it can be stated that Hungary did not 
have significantly more favourable percentages. In Central Europe, the percentages were lower in the Czech Republic and Germany, where at the age of 5 , the percentages were $2.6 \%$ and $1.3 \%$, respectively. They were higher in Bosnia, Serbia, Bulgaria, and Romania, where they were $8.9 \%, 8.8 \%$, $6.6 \%$, and $12.8 \%$, respectively [11]. According to the data of UNICEF and WHO, malnutrition is $7.7 \%$ worldwide. In 2016, more than two thirds of the malnourished lived in Asia, and more than one third lived in Africa. The situation is the most critical in South Asia, where the percentage is $15.4 \%$. It is somewhat better in Southeast Asia, where it is about $8.9 \%$. In certain regions of Africa, such as West and North Africa, the malnutrition percentages are $8.5 \%$ and $7.9 \%$, respectively, whilst in South Africa, the percentage is 5.5\%. In Ethiopia, Darsene et al. [6] studied 800 randomly selected children aged 6-59 months and found a rate of $15.3 \%$. A former study found $29 \%$ in the year 2011 [7]. The most favourable percentage in continental terms can be found in South America, where it is $1.3 \%$, in Central America, it is $0.9 \%$, and in North America, it is $0.5 \%$ [10].

For Hungary, we suggest that there is an urgent measure to be taken regarding the future assessment of the nutritional status of children in the framework of the compulsory reporting on primary child healthcare. Hungarian law stipulates that the assessment of a child's physical development and nutritional status falls within the competence of the regional visiting nurses, for whom technical guidelines are set out in Methodology Letter No. 3, titled as "Guidelines and tables for the assessment of juvenile nutritional status," issued in 2004 by the National Institute of Child Health [13, 14, 16]. Nevertheless, the assessment method is not strictly regulated. It mainly depends on the method chosen by the individual visiting nurses, and they may base their assessment on one of two options, the BMI or height alone.

Due to to the Hungarian malnutrition screening and nutritional assessment system, almost $100 \%$ of children aged between 0 and 6 years are covered by preventive care, and the data related to their normal or pathological development can be accessed. We are unaware, however, of the quality of the malnutrition screenings and nutritional assessments and the credibility of the data reported by the visiting nurses because of the aforementioned lack of strict regulation. Implementing a uniform Hungarian monitoringindicator pool based on the recommendations of the WHO is essential in order to initiate the opportunity of nationwide comparisons [21].

It seems obvious that the preparation of an information technology system for visiting nurses and the drafting of regulations requiring them to use it as a replacement for the existing paper-based documentation system are urgently needed. These measures would facilitate the capturing of data measured with certified means and evaluated with a uniform methodology including the use of calculators with automatic computing. Through the elimination of BMI percentile calculations using paper-based tables, part of the nurse visitor's daily administrative burden would be reduced, while a healthcare information technology system having a centralized national database would ensure better data quality and facilitate the preparation of up-to-date analyses and reports. By plotting regularly measured body weight and longitudinal growth data on a percentile curve, visiting nurses would be able to more intensively participate in the monitoring of the child's development. As soon as they noticed any relapse or retardation in physical development, they could immediately notify a paediatrician and demand fitting care, monitored through their occasional family visits and consulting sessions [22, 23]. Moreover, an important responsibility of visiting nurses is the strengthening of parental competence, in order to induce changes in the family attitude, which would positively affect the child's development. Because visiting nurses are key primary care experts in the timely recognition of any retardation or relapse in development caused by malnutrition, continuous updating of their professional protocols and training is essential.

The aims of this study were to map the extent of malnutrition in Hungary according to the degree of developmental disorder recognized by regional visiting nurses, to investigate regional differences in order to draw attention to the existing situation, and to encourage visiting nurses and other Hungarian healthcare professionals to solve problems, especially the problem of inconsistent assessment protocols. In the literature, we still have a scarcity of data on malnutrition among those less than 3 years of age in Hungary and Europe. In Hungarian literature, the lack of up-to-date data deserves special attention with regard to malnutrition.

Authors' contribution: MK conceptualized and designed the study, designed the data collection, coordinated and supervised data collection, critically reviewed the manuscript, and approved the final manuscript. GJSz conceptualized and designed the study, carried out the statistical analyses, critically reviewed the manuscript, and approved the final manuscript. SzM conceptualized and designed the study, designed the data collection, supervised data collection, critically reviewed the manuscript, and approved the final manuscript. LSz conceptualized and designed the study, designed the data collection, supervised data collection, critically reviewed and revised the manuscript, and approved the final manuscript as submitted.

Ethical approval: This study has been conducted in accordance with the Declaration of Helsinki and according to requirements of all applicable local and international standards.

Conflicts of Interest/Funding: The authors declare no conflict of interest and no financial support was received for this study.

\section{REFERENCES}

1. Büki Gy, Gallai M, Pasky L. A pszichomotoros fejlődés zavarainak felismerése és ellátása az alapellátás gyakorlatában [Recognizing and Managing Psychomotor Development Disorders in Primary Care Practice] [Internet]. Budapest: Országos Gyermekegészségügyi Intézet: 2. sz. Módszertani levél; 
2004 [cited 2017 Dec 20]. p. 2-27. Available from: https:// www.babanet.hu/tarsalgo/attachments/1229632646.9527.pdf

2. Cooijmans KHM, Beijers R, Rovers AC, de Weerth C. Effectiveness of skin-to-skin contact versus care-as-usual in mothers and their full-term infants: study protocol for a parallel-group randomized controlled trial. BMC Pediatr. 2017;17(1):154. doi:10.1186/s12887-017-0906-9

3. Kereki J, Major ZSB. Örzők. Egészségügyi alapellátók gyakorlatközpontú kézikönyve [Watchers. Practice-Oriented Handbook of Primary Health Care Providers] [Internet]. Budapest: Országos Tisztifóorvosi Hivatal; 2014 [cited 2017 Dec 20]. 568 p. Available from: http://mek.oszk.hu/15800/15817/15817.pdf

4. Ágfalvi R. A növekedés és a tápláltsági állapot megítélése [Assessment of growth and nutritional status]. In: Aszman A, ed. Iskola-egészségügy [School-health]. Budapest: Országos Gyermekegészségügyi Intézet; 2005. p. 85-9.

5. Shamah-Levy T, Mundo-Rosas V, Morales-Ruan C, CuevasNasu L, Méndez-Gómez-Humarán I, Pérez-Escamilla R. Food insecurity and maternal-child nutritional status in Mexico: cross-sectional analysis of the National Health and Nutrition Survey 2012. BMJ Open. 2017;7(7):e014371. doi:10.1136/ bmjopen-2016-014371

6. Darsene H, Geleto A, Gebeyehu A, Meseret S. Magnitude and predictors of undernutrition among children aged six to fiftynine months in Ethiopia: a cross sectional study. Arch Public Health. 2017;75:29. doi:10.1186/s13690-017-0198-4

7. Kar BR, Rao SL, Chandramouli BA. Cognitive development in children with chronic protein energy malnutrition. Behav Brain Funct. 2008;4:31. doi:10.1186/1744-9081-4-31

8. Asfaw M, Wondaferash M, Taha M, Dube L. Prevalence of undernutrition and associated factors among children aged between six to fifty-nine months in Bule Hora district, South Ethiopia. BMC Public Health. 2015;15:41. doi:10.1186/ s12889-015-1370-9

9. United Nations Children's Fund, World Health Organization, The World Bank. UNICEF-WHO-World Bank Joint Child Malnutrition Estimates [Internet]. New York/Geneva/ Washington, DC: UNICEF/WHO/The World Bank; 2012 [cited 2017 Oct 20]. Available from: https://www.who.int/ nutgrowthdb/jme_unicef_who_wb.pdf

10. United Nations Children's Fund, World Health Organization, The World Bank. Levels and trends in child malnutrition. UNICEF/WHO/World Bank Group Joint Child Malnutrition Estimates. Key findings of the 2017 edition [Internet]. New York/Geneva/Washington, DC: UNICEF/WHO/The World Bank; 2017 [cited 2017 Oct 20]. Available from: https:// www.who.int/nutgrowthdb/jme_brochoure2017.pdf?ua=1

11. International Food Policy Research Institute. Global Nutrition Report 2014: Actions and Accountability to Accelerate the World's Progress on Nutrition [Internet]. Washington, DC: International Food Policy Research Institute; 2014 [cited 2019 March 12]. Available from: https://globalnutritionreport.org/ reports/2014-global-nutrition-report/

12. ÁNTSZ Országos Tisztiföorvosi Hivatal: Egészségügyi Igazgatási Főosztály. Szakfelügyeleti ajánlás az alapellátásban dolgozó házi gyermekorvos/háziorvos és a területi védőnő együttmüködése helyi eljárásrendjének kialakításához [Technical Supervision Recommendation on the Development of Local Common Procedures on the Cooperation of Home Paediatrician/Paediatrician and Territorial MCH Nurse Working in Primary Care] [Internet]. Budapest: ÁNTSZ
Országos Tisztifőorvosi Hivatal: Egészségügyi Igazgatási Főosztály; 2008 [cited 2017 Dec 17]. Available from: https://www.mave.hu/uploads/file/1394-63\%20Rtfo\%20m\% 20Aj\%C3\%A1n1\%C3\%A1s\%20\%20HGYO-HO $\% 20 \%$ C3\% A9s\%20VNO\%20egy\%C3\%BCttmukodes.pdf

13. 51/1997. (XII. 18.) NM rendelet A kötelező egészségbiztosítás keretében igénybe vehető, betegségek megelőzését és korai felismerését szolgáló egészségügyi szolgáltatásokról és a szürővizsgálatok igazolásáról [51/1997. (XII.18.) NM decree on health services and certification of screening examinations of the prevention and early detection of diseases available under compulsory health insurance].

14. Joubert K. Az országos longitudinális gyermeknövekedésvizsgálat eredményei születéstől 18 éves korig (I.) [Results of the National Longitudinal Child Growth Study from Birth to 18 years of Age] [Internet]. Budapest: KSH Népességtudományi Kutatóintézet; 2006 [cited 2017 Oct 20]. Available from: https://www.demografia.hu/kiadvanyokonline/index.php/ kutatasijelentesek/article/view/394/140

15. ÁNTSZ Országos Tisztifőorvosi Hivatal. Védőnői Szakfelügyeleti Iránymutatás: A "Védőnői jelentés összesítője" havi elektronikus (on-line) adatgyüjtéssel kapcsolatban ["MCH Nurse Report Summary" on Monthly Electronic (on-line) Data Collection"]. [Internet]. Budapest: ÁNTSZ Országos Tisztiföorvosi Hivatal; 2013 [cited 2017 Nov 20]. Available from: https://www.antsz.hu/data/cms43588/Vedonoi_Szakfelugyeleti_ iranymutatas__vedonoi_adatgyujtes_jelentes_2013.pdf

16. Central Statistical Office. Yearbook of Health Statistics 2013, 2014, and Statistical Yearbook of Hungary 2015 [Internet]. Budapest: Central Statistical Office [cited 2017 Dec 20 and 2019 March 12]. Available from: https://www.ksh.hu/ docs/hun/xftp/idoszaki/evkonyv/egeszsegugyi_evkonyv_ 2013.pdf; https://www.ksh.hu/docs/hun/xftp/idoszaki/ evkonyv/egeszsegugyi_evkonyv_2014.pdf; http://www.ksh.hu/ docs/hun/xftp/idoszaki/evkonyv/evkonyv_2015.pdf

17. Pintér A. Útmutató és táblázatok a gyermekkori tápláltság megítéléséhez [Guide and Tables on the Assessment of Childhood Nutrition] [Internet]. Budapest: Országos Gyermekegészségügyi Intézet: 3. sz. Módszertani level; 2004 [cited 2017 Nov 20]. 3-35 p. Available from: http://www.futas.net/ cikkek/fogyas/bmi-testtomeg-gyermekeknel-borredo-vastagsagmerese.pdf

18. 76/2004 (VIII.19) ESzCsM rendelet Az egyes személyazonosításra alkalmatlan ágazati (egészségügyi, szakmai) adatok körének meghatározására, gyüjtésére, feldolgozására vonatkozó részletes szabályokról. [76/2004 (VIII.19) ESzCsM decree on detailed rules to define, collect and process inadequate particular identification of sector (health, professional) data set].

19. Lesiapeto M, Smuts C, Hanekom S, Du Plessis J, Faber M. Risk factors of poor anthropometric status in children under five years of age living in rural districts of the Eastern Cape and KwaZulu-Natal provinces, South Africa. S Afr J Clin Nutr. 2010;23(4):202-7.

20. Kandala NB, Madungu TP, Emina JB, Nzita KP, Cappuccio FP. Malnutrition among children under the age of five in the Democratic Republic of Congo (DRC): does geographic location matter? BMC Public Health. 2011;11:261. doi:10.1186/1471-2458-11-261

21. Aszmann A. A gyermekek fejlődésének, egészségi állapotának követése, a követés rendszerébe illesztett szürővizsgálatok hazai gyakorlata [Monitoring of children's development and health, 
Kádár et al.

the domestic practice of screening programmes embedded in the monitoring]. Népegészségügy. 2011;89(4):336-43.

22. 49/2004. (V. 21.) ESzCsM rendelet a területi védőnői ellátásról. [49/2004. (V.21.) ESzCsM decree on territorial $\mathrm{MCH}$ nurse care].
23. Odor A, Tóth Gy, Csordás Á. A védőnő preventív alapfeladatai, kötelezettsége és felelőssége a megelőző ellátásban [Preventive Basic Tasks, Obligation and Responsibility of $\mathrm{MCH}$ Nurse in Preventive Care]. Budapest: Országos Tisztiföorvosi Hivatal; 2004. p. 16-20. 